\title{
2021 Handbook of Florida Water Regulation: Introduction'
}

\author{
Michael T. Olexa, Tatiana Boriosva, and Jana Caracciolo²
}

\section{Preface}

This handbook is designed to provide an accurate, current, and authoritative summary of the principal federal and state (Florida) laws that directly or indirectly relate to agriculture. This handbook provides a basic overview of the many rights and responsibilities that farmers and farmland owners have under both federal and state laws as well as the appropriate contact information to obtain more detailed information. However, the reader should be aware that because the laws, administrative rulings, and court decisions on which this handbook is based are subject to constant revision, portions of this publication could become outdated at any time. Several details of cited laws are also left out due to space limitations. This handbook is provided as an educational text for those interested in water use and water resource issues in Florida.

This handbook is distributed with the understanding that the authors are not engaged in rendering legal or other professional advice, and the information contained herein should not be regarded as a substitute for professional advice. This handbook is not all inclusive in providing information to achieve compliance with the federal and state laws and regulations governing water protection. For these reasons, the use of these materials by any person constitutes an agreement to hold harmless the authors, the UF/IFAS Center for Agricultural and Natural Resource Law, and UF/IFAS Extension for any liability claims, damages, or expenses that may be incurred by any person as a result of reference to or reliance on the information contained in this handbook. Note: UF/IFAS is the acronym for University of Florida, Institute of Food and Agricultural Sciences.

This handbook is designed to act as a compass through the maze of statutes, regulations, and potential liabilities that identify the current mass of water protection law. Created for readers with no prior experience in law, it is designed as a necessary first step in recognizing which agricultural activities merit special attention because of their groundwater and surface water implications. It also provides an introduction to the crucial agencies and statutes that govern the realm of water protection. The law in this area is evolving rapidly as concern for the environment increases.

Because the sources and goals of the existing environmental statutes vary, the law as a whole has not developed with systematic precision. Current water regulation law presents a confusing array of overlapping, unclear, and sometimes contradictory mandates, and, consequently, can be a formidable barrier to both lawyers and laypersons struggling to determine their exact rights and responsibilities. Perseverance is necessary because penalties or liabilities in some instances are quite substantial.This work is not a comprehensive study and therefore should not be regarded as the final word on any of the topics discussed. Rather, the reader should view this publication as a means to determine

1. This document is FE580, one of a series of the Food and Resource Economics Department, UF/IFAS Extension. Original publication date October 1998. Revised June 2017 and April 2021. Visit the EDIS website at https://edis.ifas.ufl.edu for the currently supported version of this publication.

2. Michael T. Olexa, professor, Food and Resource Economics Department, and director, UF/IFAS Center for Agricultural and Natural Resource Law; Tatiana Borisova, associate professor, Food and Resource Economics Department; and Jana Caracciolo, student, Levin College of Law; UF/IFAS Extension, Gainesville, FL 32611.

The Institute of Food and Agricultural Sciences (IFAS) is an Equal Opportunity Institution authorized to provide research, educational information and other services

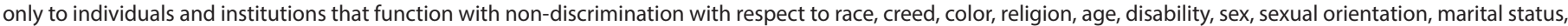
national origin, political opinions or affiliations. For more information on obtaining other UF/IFAS Extension publications, contact your county's UF/IFAS Extension office. U.S. Department of Agriculture, UF/IFAS Extension Service, University of Florida, IFAS, Florida A \& M University Cooperative Extension Program, and Boards of County Commissioners Cooperating. Nick T. Place, dean for UF/IFAS Extension. 
the areas in which to seek more information and as a brief directory of agencies that can help answer more specific questions. Federal and state agencies are unquestionably the best sources for specific questions because they are in close touch with both the formal and practical considerations of the areas they regulate. For addresses and/or telephone numbers of the agencies and divisions, see FE616, Contact Agencies. These agencies can provide more information on the topic, answer specific questions, and often supply free literature.This handbook's effectiveness can only be enhanced by the submission of ideas and suggestions about the scope and quality of its coverage. Comments regarding any areas that may have been omitted but deserve inclusion would be particularly valued. Reader feedback is a necessary ingredient to complete any successful future editions. With this in mind, please send any comments or suggestions to the following address:

Michael T. Olexa, Ph.D., J.D.

UF/IFAS Center for Agricultural and Natural Resource Law Post Office Box 110240

Gainesville, FL 32611-0240

\section{Acknowledgments}

The authors are indebted to the personnel of both state and federal agencies who provided their time and advice in the preparation of this handbook. We acknowledge Carol Fountain and Susan Gildersleeve at the University of Florida for their assistance in editing this handbook. We also acknowledge funding received for updating this publication from the James S. and Dorothy F. Wershow UF/ IFAS Center for Agricultural and Natural Resource Law Endowment. 